\title{
Continuity and change in the institution of town and country planning: modelling the role of ideology
}

Article

Accepted Version

Shepherd, E. (2018) Continuity and change in the institution of town and country planning: modelling the role of ideology.

Planning Theory, 17 (4). pp. 494-513. ISSN 1741-3052 doi: https://doi.org/10.1177/1473095217737587 Available at https://centaur.reading.ac.uk/72724/

It is advisable to refer to the publisher's version if you intend to cite from the work. See Guidance on citing.

To link to this article DOI: http://dx.doi.org/10.1177/1473095217737587

Publisher: Sage

All outputs in CentAUR are protected by Intellectual Property Rights law, including copyright law. Copyright and IPR is retained by the creators or other copyright holders. Terms and conditions for use of this material are defined in the End User Agreement.

$\underline{\text { www.reading.ac.uk/centaur }}$

\section{CentAUR}


Central Archive at the University of Reading

Reading's research outputs online 


\title{
Continuity and change in the institution
}

\section{of town and country planning: Modelling}

\section{the role of ideology}

\author{
Edward Shepherd
}

(School of Real Estate and Planning,) University of Reading, UK

\begin{abstract}
The institution of town and country planning rests upon ideas and concepts which will always be contested. Such concepts include 'liberty', 'community', 'society' and 'the state'. It is a function of political ideology to seek to fix the meanings of contested concepts and thus exert control over political reality. By analysing the particular conceptual structure of the ideologies which seek to influence planning from positions of political power, the analyst can show how these ideologies are related to shifts in the conceptual and institutional structure of planning. The paper illustrates this analytical method in the context of the transition from the ideology of New Labour to the ideology of the Conservative-led Coalition government in England after 2010.
\end{abstract}

Key words: ideology, political ideologies, planning, institutional change, localism, regions, Michael Freeden

Accepted for publication to Planning Theory journal on Friday 15 September 2017. Please refer to published version for referencing purposes. 


\section{Introduction}

This paper suggests a theory for the study of the relationship between shifts in the political ideologies of national governments, and shifts in the institutional frameworks for planning at the national level over time. That there exists a relationship between ideology and planning policy and practice is by no means a novel insight (Foley, 1960). Much of planning theory engages with this idea to a greater or lesser degree. It is therefore not the fact that this relationship exists which is interesting. Rather, the interest and utility lies in trying to understand the nature of the relationship and through doing so, develop a deeper understanding of the political nature of planning and how its meaning and purpose may be subject to ideological influence which finds expression in institutional shifts at the political centre.

There are many incarnations of the concept of ideology and each may reveal something different about planning. Eagleton (2007) identifies six different definitions of ideology which may here be simplified to three: the general production of ideas, beliefs and values in social life (an understanding which approaches the broader concept of 'culture'); the mobilisation of ideas, beliefs and values in the promotion and legitimation of sectoral interests against opposing interests; and a third more pejorative form in which ideas, beliefs and values are mobilised to legitimise powerful interests through distortion and misrepresentation. Each of these broad definitions (which are by no means exhaustive) conceals a multitude of different but overlapping intellectual traditions and analytical 
methods. The challenge is therefore to select a tradition which is suited to the analysis of the problem at hand.

The problem is the indeterminacy of planning as an idea and activity and the related institutional instability of planning at the political centre. There is a well-remarked lack of consensus in the planning literature and in the world of practice as to what precisely planning is and what it should be aiming to achieve. There is also a history of reform and national institutional adjustments to planning in many national contexts, including the UK (Cullingworth et al, 2006; Tewdwr-Jones, 2012), the Netherlands (Nadin \& Stead, 2012; Zonneveld, 2005), France and Germany (Waterhaut et al, 2013). It is a truism that this indeterminacy and adjustment is partly a function of the variety of ideas, beliefs and values which influence the institution of planning at various points in its history and in various national contexts.

This paper therefore proposes an approach for the study of the relationship between ideology and institutional changes in planning at the political centre which is based on a theory of ideology which frames it as comprising mutable structures of essentially contested political concepts whose role is to fix, control and simplify indeterminate and complex political meaning (Freeden, 1996, 1998, 2003, 2013). This 'morphological approach' therefore straddles the second and third definitions given above; it is about legitimation of sectoral interests as they relate to planning, which may involve a degree of distortion and misrepresentation through rhetorical effects. 
Freeden's morphological approach was developed to analyse the great political ideological families such as 'liberalism', 'conservatism' and 'socialism'. However, planning is not an ideology in these terms. Contemporary planning is better conceived of as an institutionalised construct which has assembled over time under various ideological influences, rather than as an ideology which aspires to coherence and is aimed at delivering political transformation. Freeden's approach therefore needs to be developed and adapted for the problem at hand.

By incorporating insights from the 'ideational turn' in political science and discursive or constructivist institutionalism (Béland \& Cox, 2011; Blyth, 2002; Schmidt, 2010), this paper theorises planning as comprising ideas and concepts which have discursively interacted with the policymaking process and been adopted as part of the institutional framework. Shifts in the meanings of concepts important to planning in the ideologies of those in political power can therefore be expected to be expressed in some way through shifts in the institutional framework for planning which is partly shaped by those concepts and the relations between them.

In this theory, while planning is not a political ideology per se, it gains its form and structure by virtue of the fact that it is structured by concepts which are of key concern to political ideologies. It therefore becomes a focal point for deep contestation and institutional adjustment as political ideologies struggle to impose control over the terms by which these concepts are understood and, therefore, control the limits of what is thinkable in planning practice. The planning literature is more commonly concerned with 
the analysis of instances of such practice. However, there is a need to develop a fuller understanding of what is happening at the political centre and how this creates the framework which shapes the terms by which practitioners conduct their work.

The English context has been selected in order to illustrate the theory here. England provides fertile ground for the study of ideology and change in planning due to its near constant rate of seemingly ideologically-driven institutional shifts, so that 'planning reform is now with us on a near permanent basis' (Allmendinger and Haughton, 2015: 29). The most recent period of significant change came following the election of the Coalition government in 2010, when a largely Conservative agenda for planning was swiftly introduced, resulting in the dismantling of significant parts of the national system which had been put in place by the previous Labour government. This included the abolition of national statutory regional planning, the introduction of a new tier of planning at the neighbourhood level, and the replacement of over 1,000 pages of national planning policy guidance with a single National Planning Policy Framework (NPPF) of just under 60 pages.

Due to the governance structure of English planning, whereby the direction for local policy is set at the national level by politicians and civil servants who are increasingly subject to the influence of privately funded think tanks (Haughton and Allmendinger, 2016), it is clear that practitioners embedded within the institution at various scales have had their professional practice adjusted by shifts in the political thinking of those in positions of power in central government. Planning practitioners in England, whether 
they be local authority planning officers, planning inspectors, High Court judges or consultants, have therefore been made subject to the intellectual influences of ideologues. The task is to analyse and understand this relationship.

\section{Theorising ideology: contestation and the morphological}

\section{approach}

There have been few attempts to develop a theory of ideology as a tool specifically suited to analysing the relationship between national political ideologies and institutional adjustments in planning at the political centre over time. Such a theory needs a number of characteristics. It needs to be systematic and therefore capable of being applied in the same way to different instances of ideological change at different points in planning's history so as to be able to assess the degree of continuity and change. It needs to acknowledge that political ideologies are not fixed, clearly bounded phenomena, but are plural, porous, subject to change and can move on to the ideological territory of rival systems depending on historical context. The theory also needs to accept that while

political ideologies may aspire to coherence, they are often riven with logical contradictions and dilemmas.

The morphological approach for the analysis of political ideologies has these characteristics and can therefore be adapted to help us think about the problem at hand. Developed by political theorist Michael Freeden, this approach conceives of ideologies as 
'distinctive configurations of political concepts...[that] create specific conceptual patterns from a pool of indeterminate and unlimited combinations' (Freeden, 1998: 4). For Freeden, political concepts are the 'units of political thinking', and the 'meaning' of an ideology therefore derives from the morphology of political concepts comprising it. A concept such as 'social justice' or 'public good' therefore derives its meaning from how it relates to other concepts within an ideology. Crucially, this morphology is not fixed, but can shift across space and time.

For Freeden, the concepts comprising an ideology are 'essentially contested'. This explicitly draws on W.B. Gallie's notion of 'essentially contested concepts', which are 'appraisive', 'internally complex', and are 'open to modification in the light of changing circumstances' (Freeden, 1998: 55). Concepts identified as essentially contested include the 'big' political philosophical concepts such as 'democracy' and 'liberty'. Due to this essential contestability, employment of such concepts 'inevitably involves endless disputes about their proper uses on the part of their users' (Gallie, 1956: 169).

This understanding of ideologies simultaneously acknowledges a post-structuralist indeterminacy of meaning in language while also framing ideologies as structuring and 'cementing the word-concept relationship' (Freeden, 1998: 76) through shutting out alternatives (a process Freeden refers to as 'decontestation'): 'the decontesting of political concepts performed by an ideology is an attempt to legitimate a preferred political order by controlling the meaning of key political words' (Freeden, 1998: 117). Freeden gives examples of such concepts as liberty, rights, equality, justice, and democracy (Freeden, 
1998: 61). In Gallie's terms, to use such a concept 'means to use it against other uses and to recognize that one's own use of it has to be maintained against these other uses...to use it both aggressively and defensively' (Gallie, 1956: 172).

Importantly, the morphological approach emphasises the mutable structure of political ideologies. Freeden's approach identifies three 'levels' or positions of concepts within the morphological structure of an ideology: the core, adjacent and peripheral. Concepts situated at the core of an ideology are of most fundamental importance, while the adjacent concepts furnish the ideology with greater richness and nuance. Peripheral concepts are of less fundamental importance to the structural integrity of the ideology and can include 'perimeter' concepts which are theorised as being 'specific ideas or policyproposals rather than fully fledged concepts' (Freeden, 1998: 78). Peripheral concepts are the means by which a political ideology interfaces with the political world.

The conceptual structure of an ideology may change across time and space, thus changing the ideology. The English liberalism of 2017 is different from the English liberalism of 1859, and both are different from American liberalism in 1993. All of these members of the broader ideological family of liberalism will have different implications for political institutions and policy programmes. There is therefore a specific concern with history in the morphological approach, which acknowledges the relationship between historical and spatial context and human consciousness. Ideology does not exist in a temporal and spatial vacuum; it can shape and be shaped by geography and history. Nevertheless, the role of an ideology is paradoxically to seek to confront this flux and fix the meaning of 
the essentially contested concepts and, therefore, the meaning of political reality, however temporarily and imperfectly.

Perhaps the most helpful element of Freeden's method is that by focusing on concepts as units of analysis, his approach allows for a nuanced understanding of ideology whereby 'different' ideologies may share some of the 'same' concepts, yet they are decontested and structured in different ways and therefore have different meanings. Or, alternatively, that the 'same' ideology may comprise concepts which become decontested and structured in different ways over time. Thus, the different ideologies of social democracy and liberal democracy might have the same conception of the concept of democracy within their structure (Dommett, 2012: 21), and these two ideologies may also change over space and time as a consequence of changes in their conception of democracy. Through this conception, we can therefore move beyond the simple two dimensional 'left-right' axis of political thinking and into a theory which is able to model the richness and variety of 'living' ideologies and how they may change.

\section{The ideology of the institution of planning}

The morphological approach to the study of ideology has suggestive implications for a theory of the relationship between ideology and institutional change in planning. However, it needs to be adjusted to be suited to the analysis of the problem at hand. This paper therefore combines the morphological approach with insights from the 'ideational turn' in political science and discursive or constructivist institutionalism (Béland \& Cox, 
2011; Blyth, 2002; Schmidt, 2010) in order develop a theory which can help us think about the relationship between political ideologies and institutional change.

If ideologies comprise shifting structures of essentially contested political concepts whose function is to simplify and control the proper meaning and structure of political thinking, then if a political idea such as planning is structured by some of those concepts which are hotly contested by competing ideologies, then planning will be a site for ongoing contestation as ideologies struggle for mastery over the meanings of concepts central to planning. Because 'planning' is itself a political idea (Reade, 1987: 177), change in planning then becomes partly a function of ideological competition over the proper meanings of the concepts which it shares with competing ideologies.

The task for the analyst is therefore to identify those political concepts which are of structural importance to planning and which are shared with political ideologies, and to identify whether and how their meanings and relational structure has changed over time. The theorist can thus conceptualise planning as comprising a morphology of essentially contested concepts which give it form and meaning. Planning and the political concepts comprising it therefore become the objects of analysis. Yet, planning as object is also a subject because it is subjected to ideological influence.

The conceptual structure of the institution of English planning at the centre can therefore be analysed in terms of how the political concepts that comprise it are decontested and their meanings temporarily fixed by those in positions of political power. In this way, 
Freeden's theory for the analysis of ideologies can be adapted to the analysis of an institution as comprising institutionalised ideas and concepts (Hay, 2002, 2009; Schmidt, $2008,2010,2011)$. This form of analysis does not therefore seek to identify the ideology of planning. Instead, it seeks to identify the ideology of the institution of planning. That is to say, through an analysis of the institutionalisation of various contested concepts at various points in time, the ideology (or ideologies) of the institution of national English town and country planning may therefore also be analysed.

The contested concepts of key structural importance to planning will be different in various national political contexts. However, in the English context such concepts include liberty, property, the state, society and community ${ }^{1}$. These concepts have been at the very heart of the institution of English planning since its stirrings in the decades leading up to the Town and Country Planning Act 1947 and the subsequent nationalisation of development rights, which according to a contemporary commentator institutionalised 'the affirmative claims of the community upon property rights to an extent never before seen in common law countries' and in doing so represented 'a significant change in Western thought with respect to the balance struck between the individual's rights in land as against those of society' (Haar, 1951: 2).

Indeed, planning is the policy area par excellence for thinking about the proper degree of state intervention in private property rights and personal freedoms in the interests of the freedoms of wider society and local communities. This is what planning is about at its

\footnotetext{
${ }^{1}$ Other concepts include 'Plan' and 'Town' and 'Country', but the role of these concepts is not analysed in this paper. For a fuller analysis, see Shepherd (2016).
} 
core. In planning theory, we are used to thinking of contested concepts in terms of concepts such as 'sustainable development', 'region' or 'public interest' (for other candidates, see Parker and Doak (2012)). However, within the theory proposed here, these concepts become adjacent to core concepts such as liberty, the state, community and society. These adjacent concepts arise to furnish the core concepts with greater nuance and give them a spatial and environmental dimension. They find concrete expression at the ideological periphery in policy ideas such as 'Environmental Impact Assessment', 'regional spatial strategy' and the various forms of land value capture policies to name a few. The task of the analyst is to trace these relationships.

This theoretical framework will now be briefly illustrated through a summary of the ideological contestations surrounding the creation and abolition of statutory regional planning and the introduction of a more 'local' form of neighourhood planning shortly after the election of the Conservative-led Coalition government in 2010. These are just two of the many planning reforms introduced, so what follows does not claim to be a complete analysis of the relationship between political ideology and institutional change at that particular time. It focuses only on the articulation of a small number of concepts. However, it is hoped that by setting out such a 'snapshot', the potential of the theory to more broadly analyse the relationship between political ideologies and institutional change in planning in different times and geographical contexts may be made clear.

However, as the period of UK political and institutional history being analysed here is the transition from the New Labour government of 1997 - 2010 to the Conservative-led 
Coalition government of 2010 - 2015, the British political context will now be briefly summarised for the benefit of those not familiar with British politics.

\section{The British Political Context}

The Labour Party was elected to power in 1997 after 18 years of Conservative rule. The 'New Right' Conservative leadership of Margaret Thatcher and then John Major had succeeded in neoliberalising the political landscape, so that by the 1990s the socialist Old Left of the Labour Party seemed antiquated. The Labour Party would therefore have to respond by 'modernising'. This would give rise to New Labour.

Tony Blair was elected as leader of the opposition in 1994 and the New Labour agenda was put into action. Blair swiftly announced plans to recast the aims and values of the party, and in 1995 revised the wording of Clause IV of the Labour Party's constitution, removing the party's commitment to the 'common ownership of the means of production' and replacing it with an emphasis on the 'strength of common endeavour' to create a community in which 'power, wealth and opportunity are in the hands of the many, not the few' (Labour Party, 2014: 3). The Labour Party now had new freedom to adjust its political project and respond more flexibly to what leading party figures saw as a new political and economic context to which old ideas could no longer apply unaltered.

New Labour's resultant 'Third Way' project was based on 'uniting the two great streams of left-of-centre thought - democratic socialism and liberalism' (Blair, 1998: 1). This 
involved rediscovering the concepts of liberty and community which had previously been emphasised as part of ethical socialism and the communitarian liberalism of T.H. Green (1836-82), J.A. Hobson (1858-1940) and L.T. Hobhouse (1864-1929), for whom liberalism meant 'a fuller realisation of individual liberty contained in the provision of equal opportunities for self-development' (Hobson as quoted in Eccleshall, 1986: 204).

This represented a transformation in how the concept of liberty was understood, from the emphasis on 'negative' liberty of classical liberalism which conceptualised the individual as a rational self-determining agent with 'freedom from' constraint in the context of the assumed rationality of an ideally non-constrained market, to a more 'positive' conception of liberty (Berlin, [1958] 2001). This meant 'a positive power or capacity of doing or enjoying something worth doing or enjoying...a power which each man exercises through the help or security given him by his fellow-men' (Green, 1888: 371); in other words, a conception of liberty implying an individual with 'freedom to' rationally selfdevelop and grow within a mutually supportive collective in the context of a market constrained only to the degree required to support this form of liberty.

This implied a role for redistributive state power to help remove social and economic inequalities and create the conditions in which individuals and communities have more equal opportunities to develop. It was this kind of political thinking which partly lay behind the establishment of the welfare state in Britain in the 1940s to which the origins of the modern institution of English planning were closely related. However, for New Labour equality of opportunity for self-development would not be secured mainly 
through state redistribution, which would be relegated to be just one of many means, and 'emphatically not an end in itself' (Blair, 1998: 1). Thanks to the liberal strand of New Labour ideology, economic growth would also be a means by which social justice objectives could be secured. It was for these reasons that the 2005 Labour Party manifesto claimed that 'economic dynamism and social justice must go hand in hand' (Labour Party, 2005: 15). The Third Way was therefore an amalgam of social democratic and liberal ends, to be delivered through flexible means.

New Labour won the 1997 general election and in the ensuing 13 years seemingly succeeded in adjusting the political terrain again, to reflect New Labour's ideological project. Meanwhile, the Conservative Party floundered. When David Cameron was elected leader of the Conservative Party in 2005, he inherited a party which had lost three general elections in a row and was in disarray. Cameron engaged in a project to ideologically reposition the Parliamentary Conservative Party so that it could pose a realistic challenge to New Labour's territory (both ideological and electoral).

This would involve reconnecting with an older 'One Nation' (and ostensibly more socially aware) current of conservative thought (Dorey, 2007: 162), and through it apparently acknowledge the concept of social justice, which was to be radically transformed by an accompanying 'potent anti-statism and emphasis upon individual responsibility' (Evans, 2010: 327). The Conservative Party would therefore be able to claim in Built to Last: the Aims and Values of the Conservative Party that it would 'fight social injustice and help the most disadvantaged by building a strong society' 
(Conservative Party, 2006: 5), but without calling for an expansion in the size of the state in order to deliver it.

Instead, the concept of community (transformed from that used by New Labour) would be called on to fill the conceptual space left by a receding state. This would be coupled with a neoliberal conception of liberty, whose destabilising tendency would be theoretically controlled by the call for communities to take responsibility for looking after each other and their neighbourhood's physical fabric, identity and institutions, while still allowing for a continuing emphasis on individual responsibility and enterprise within a market economy. The interaction of the Cameronite decontestation of the concepts of liberty, community, society and the state would result in an overt localist impulse.

It is this ideological amalgam which would provide the overarching framework which would shape the Parliamentary Conservative Party's programmatic and policy ideas relating to planning. However, the electorate was not fully convinced and Cameron could only deliver a partial victory in the 2010 general election. The Conservative Party was forced to form a coalition government with the Liberal Democrats, an uneasy alliance which lasted until 2015 when Cameron finally delivered a full general election victory.

\section{New Labour - conceptual contestations}

In accordance with the liberal strand of New Labour's ideology, a key role for planning was initially framed as being to function predictably and efficiently so as to promote 
greater economic development (DTLR, 2001, 2002). We see here what looks like a continuation of the New Right neoliberal ideology. However, what prevented the New Labour ideology as manifested in the institution of English planning from being a continuation of the agenda set by the New Right was the insertion of the concept of community, an adjusted concept of liberty, and a different understanding of the enabling state in planning terms. The interaction of these abstract concepts would find institutional expression through the adjacent concept of the region, the peripheral concept of the regional spatial strategy and the extension of central state power through statutory planning these concepts represented.

According to the ideology of New Labour, the planning system was a means which could contribute to communitarian ends through helping to enable the smooth operation of the market and the growth of the economy in the interest of a broader distribution of opportunity and freedom to self-develop. The state would ostensibly play a supporting and enabling (rather than controlling) role in helping this to happen. This vision for the state allowed the space for an old social democratic concept to re-enter the core of the ideology of the institution - that of 'community' (as a transformed manifestation of the broader concept of 'society').

The concept of community 'has been a persistent one in socialist thinking' (Barker, 1997: 270), and has traditionally meant for social democrats 'an egalitarian and cooperative society in which individuals identified with the commonwealth at least as much as with their own material advantage' (Bevir, 2005: 69). It is also a concept core to the 
communitarian liberalism which New Labour 'rediscovered', for which community was a means by which the rational self-development of individuals could be mutually supported for the common good.

By emphasising the concept of community, New Labour was therefore able to stress 'the commitment individuals have as citizens, and the responsibilities they owe in exchange for certain benefits and rights they are entitled to' (Beech, 2004: 95). Crucially, it 'denies that successful economies live by competitive individualism alone' (Driver \& Martell, 1997: 33), and therefore enabled New Labour to differentiate itself from the neoliberal New Right and its seemingly 'uncaring' denial of a collective and cooperative society.

Furthermore, by calling upon the concept of community rather than that of 'society' which for ideological opponents had statist connotations due to the perceived tendency in socialism of allowing the state to assume a too powerful role as arbiter of societal good, New Labour sought to distance itself from the caricature of monolithic and controlling statism which critics of socialism so detested. The concept of community was thus summarised by Blair as 'a modern idea of community ... which applauds and nurtures individual choice and personal autonomy and which recognises the irreducible pluralism of modern society' (as quoted in Buckler, 2007: 46). It was therefore a concept of community which welcomed social freedom and multiculturalism.

What the core concept of community and its relationship with the enabling state meant for the ideology of the institution of national English planning was an apparent emphasis 
on the devolution of power to local communities to determine development in their own interests (Tewdwr-Jones, 2002: 58). The 2001 Labour Manifesto stated: 'Government cannot achieve social inclusion for people, but it can help them achieve it for themselves, by transferring power and opportunity to local communities' (Labour Party, 2001: 24). In this sense, the core concept of liberty was interpreted to mean freedom to realise planning and development opportunities for the good of the community, through a simultaneous greater degree of freedom from overt centralised state direction and control. The government green paper Planning: Delivering a Fundamental Change (DTLR, 2001), alongside a 'business agenda', therefore emphasised the need to engage the local community, 'including local business, residents, tenants and voluntary groups' (DTLR 2001: 16), and local authorities were required to develop Local Strategic Partnerships to 'establish effective mechanisms for community involvement' (DTLR 2001: 16).

However, this form of localism was in actuality not to be without a significant degree of strategic state oversight. There was not to be enhanced negative freedom from centralised state intervention, and there was not to be significant devolution of plan-making power to local communities. Towards the end of the Thatcher period and then under her successor John Major, there was a shift away from the 'project-led' planning system towards a more strategic and 'plan-led' system which saw a partial revival of regional planning and a proliferation of national planning guidance (Allmendinger \& Thomas, 1998). This shift was continued and consolidated by New Labour and, through this, the concept of the region assumed key structural importance in the ideology of the institution of planning through its position adjacent to the core concepts of the state, liberty and community. It 
would be through the concept of the region that New Labour's positive conception of liberty and the state supervision it called for would find expression and the tensions inherent in its ideology would manifest.

The government green paper Planning: Delivering a Fundamental Change (DTLR, 2001) set out the proposed response of the planning system to the new regionalist agenda. It proposed replacing regional planning guidance with statutory Regional Spatial Strategies (RSSs) which would 'outline specific regional or sub-regional policies, address the broad location of major development proposals, set targets and indicators where necessary' (DTLR, 2001: 21). The proposals were reiterated in Sustainable Communities: Delivering Through Planning (DTLR, 2002) and were formally introduced through the Planning and Compulsory Purchase Act 2004.

The concept of the region, and the form of planning it represented, acted as a focal point for latent tensions in the ideology of the institution of English planning under New Labour. Regional planning was framed as representing devolution of power away from central government to the regions, and therefore the redistribution of freedom of opportunity at regional and local community level. However, the introduction of statutory RSSs inserted an additional level of statutory planning at the regional level in between national planning guidance, and local plans while abolishing county-level structure plans. The new RSSs would be prepared by Regional Assemblies which were indirectly elected regional bodies partly comprising representatives from county and district councils. The concept of 'community' in this context was therefore not very local. 
In theory the planning space created by RSSs would be filled from the bottom up, and not from the top down. However, given that RSSs had to be in accordance with national planning guidance (checked by central state 'outposts' Government Offices for the Regions), that local plans had to be in accordance with them, and that they imposed targets for housing delivery on sometimes unwilling local authorities, they can also be seen as avatars for the central state at regional level. This was a view taken by Conservative shires, whose opinions were voiced by Conservative MP Eric Pickles who saw RSSs as reducing the degree of freedom at county and local level by 'dragging in a more remote regional authority, thereby breaking the link with decisions made by local people' (HC Deb 17 Dec 2002, c 738), while New Labour thinking saw them as a necessary expansion of state power into regional political and geographical space in order to provide strategic oversight and ensure that the benefits of economic growth and good planning could create a broader distribution of opportunity and, therefore, freedom.

This reveals the tension arising from the New Labour ideological project of combining liberal with social democratic ideas, particularly around the concepts of liberty and the state. On one hand, the ideology held that the planning system should be more streamlined and responsive to business in the interests of economic growth and the broader distribution of opportunity it would bring. This would require a 'light touch' enabling state at the local level, and partnership and cooperation at the regional level so that communities could come together and deliver economic growth in a way responsive to regional context and free from too much central state direction. As such, regional 
planning was presented by New Labour as a devolution of power away from the central state and, in theory, greater freedom for local authorities and communities. On the other hand, local authorities (and the communities they represent) could not be trusted by New Labour to be given the responsibility to come together and work effectively at regional level without a statutory requirement from the centre to prepare an RSS which had to plan to deliver centrally-set housing targets.

This distrust of the local level of state activity in the ideology of the central institution of English town and country planning at the time can be seen as an example of what Jessop (2003: 152) has identified as the 'disciplinary role' of the state under New Labour, as this statutory requirement represented a significant degree of central state intervention in regional (and local) affairs. Such central state involvement by New Labour suggests that it was ideologically predisposed to expanding state intervention through planning (in the interests of coordination to achieve a broader distribution of liberty through opportunity in the market), despite its other ideological emphasis on the need for an efficient and enabling state.

It would be these statutory regional aspects of planning and associated regionallyimposed targets for the delivery of housing which would be particular areas of argument in the years up to and following the election of the Conservative-led Coalition government in 2010. This was partly due to the fact that the concepts of liberty, the state, society and community were important concepts in conservative ideology as well as New Labour's, but that they were decontested and articulated in different ways. This 
fundamentally changed the role of the concept of the region in the ideology of the institution of planning, and therefore in the policies associated with it. Furthermore, the incoherence of these policies when taken together can be seen as being partly a function of the underlying incoherence of the abstract conceptual structure of the dominant ideology in the Conservative Party at the time, resulting from an attempt to reconcile fundamentally competing ideological imperatives arising from the intersection of a more 'negative' form of liberty, and a conservative conception of community.

\section{Cameronite Conservatives - conceptual contestations}

When David Cameron was elected as leader of the Conservative Party in 2005, he engaged in a campaign to ideologically reposition the Conservative Party so that it could pose a realistic challenge to New Labour. To achieve this, he drew on the thinking of a number of key figures in and around the party. These included David Willetts who developed the concept of 'Civic Conservatism' which was an attempt to 'reconcile free markets (which deliver freedom and prosperity) with a recognition of the importance of community (which sustains our values)' (Willetts, 1992: 92); Oliver Letwin who developed the conservative concept of the 'Neighbourly Society' and who would go on to be a main architect of the Coalition agreement in 2010; and Philip Blond, a centre right academic. In different ways, these thinkers were concerned with the proper meaning of and relationship between the concepts of liberty, society, community and the state, and how a rearticulation of these concepts within conservative ideology might be employed to 
update the Conservative Party. This rearticulation of the ideology of the Parliamentary Conservative Party would have significant implications for the institution of planning.

A key concern of Willetts and Blond in particular was how to manage the threat to British conservatism which was posed by the implications of the New Right's insertion of a neoliberal conception of liberty into Conservative Party ideology. This threat arose from the tension between this conception of liberty (as freedom from coercion and the economic and social liberalism this implied), and a conservative conception of society. Given Margaret Thatcher's infamous claim in an interview with Woman's Own magazine published on 31 October 1987 that 'there is no such thing as society', it may seem contradictory to claim that 'society' is an important concept in conservatism. However, the concept of the 'organic society' is a crucial element of a more traditional preneoliberal 'One Nation' English conservatism. This is a vision of society that is steeped in a respect for history and tradition, and therefore sees the existing identities and institutions of society as having arisen 'naturally' or 'organically' and therefore valuable in their own right and to be conserved (Heywood, 2012: 75).

This means that the neoliberalisation of the Conservative Party under the British New Right after 1979 could be perceived by some traditional conservatives as a threat. This has been expounded in some detail by philosopher John Gray: 'Market liberalism...fosters a privileging of choice and a cult of mobility that consort badly with the settled communities cherished by traditional conservatives' (Gray, 1997: 23). A surfeit of social and economic freedom therefore poses a threat to those histories, 
traditions and identities which the conservative is supposed to want to conserve. The unsettling dynamism of a neoliberal conception of liberty also brings with it the loss of valuable local knowledge, which is rendered 'obsolete or irrelevant to the operation of market processes that are themselves ever more disembodied' (Gray, 1997: 40). A conservative should mourn this loss, 'because such knowledge is constitutive of our very identity, is a central value in any outlook that is truly conservative' (Gray, 1997: 39).

However, whereas Gray concluded that '[t]he hegemony, within conservative thought and practice, of neo-liberal ideology has had the effect of destroying conservatism as a viable political project of our time' (Gray, 1997: 3), David Willetts took a different view. Willetts argued for a conservative engagement with the 'creative tension between...our belief in individual freedom, private property and the market economy on one hand, and on the other a commitment to maintaining the institutions which hold our nation together' (Willetts, 1997: 169). Willetts, addressed this 'creative tension' (or underlying incoherence) by retaining the concept of liberty as central to modern conservative thought, while arguing that it needed to be anchored somehow, so that its destabilising influence could be controlled. It was the concept of community and, through it, the broader concept of society which could perform this function. For Willetts, the Party needed to acknowledge a 'Conservatism not just of economic and personal freedoms but also of social reform to create a stronger society. What it understands is that freedom is not enough on its own' (Willetts, 2005). The conception of community invoked was therefore a distinctly conservative one which viewed it as a 'source of stability' with 
community relationships acting as 'a source of moral regulation rather than free selfdevelopment' as under New Labour (Buckler, 2007: 42).

This chimed with Blond's analysis, for whom the solution must be 'grounded in a conservatism with deeper roots than 1979 , and whose branches extend into the tradition of communitarian civic conservatism' (Blond, 2009). Blond thus argued for a radical conservatism which acknowledges the value of local communities and institutions in combination with a suspicion of the remote and totalitarian 'monopoly capitalism' which is the result of international market liberalism. Willetts and Blond therefore sought to position the concept of community as a stabiliser to a neoliberal form of liberty. In doing so, they sought to refocus from the atomised individual economic agent 'floating freely, untrammelled by ties, culture or history' (Willetts, 1997a: 82), to the agent as a node within a community network comprising individuals bound together through valued national and local institutions.

There are obvious similarities here with the New Labour ideological project. New Labour had also invoked the concept of community in order to balance the individualism implied in the concept of liberty which it reclaimed from its ethical socialist past, but which had been transformed by the post-New Right neoliberal context. The concept of community was therefore employed to legitimise the Party's turn to liberalism and differentiate itself from the 'uncaring' Conservative Party through its connotations of communal fellowship. New Labour with its championing of multiculturalism was less concerned with the challenge of market liberalism to traditional community identities and institutions which 
so preoccupied conservative minds. Furthermore, New Labour's more positive conception of liberty, which emphasised equality of opportunity to rationally self-develop within a community also brought with it a degree of redistributive state intervention and oversight which was anathema to conservatives. For New Labour, individuals within a community could achieve self-development through the supportive operations of the state.

For conservatives such as Willetts, Blond and Letwin however, such state activity posed a threat to traditional communities by suppressing local identity. It also represented an unacceptable constraint to individual liberty which was decontested in conservatism in a more negative sense, particularly following the neoliberalistion of the 1980s. The implications of a retained yet controlled neoliberal conception of liberty was a continued mistrust of attempts by human reason to predict, control and plan as this would represent an unacceptable level of interference with the natural and organic order of society and the market which was conceived as the forum in which society could find free expression. It is these relationships between the concepts of liberty, community, society and the state which was the focus of Letwin's Neighbourly Society concept.

Letwin, who oversaw the authorship of a set of three interlinked Conservative Party green papers which were produced in the run-up to the 2010 general election and which set out the party's programme for town and country planning (Conservative Party 2009a, 2009b, 2010), has rhetorically argued that 'when the Left say 'society'...they inevitably mean the state' (Letwin, 2002). It was this which he saw as lying behind the overtly centralised 
bureaucracy which was a product of New Labour's belief that 'the State is the great engine by which society will improve the condition of mankind' (Letwin, 2003: 46). However, for Cameronite Conservatives the effect of such state intervention was to erode society, not strengthen it (Evans, 2010: 331). Instead of the state solving people's problems, responsibility (and therefore empowerment) must fall to 'a society composed of active citizens, strong families and of neighbours who look out for each other' (Letwin, 2002). In short, a society comprising strong local communities.

For Letwin, the synthetic (rather than organic) bonds created by the central state should play less of a role in society and interfere less in local communities because it is the impulse to create social equality which stifles local difference, the freedom of local institutions and the social bonds tying a community together. Central state intervention for Letwin therefore disempowers local communities and is blind to important local context and the local knowledge which Gray has identified as 'a central value in any outlook that is truly conservative' (Gray, 1997: 39). The answer is therefore 'to adopt...an attitude of thoroughgoing localisation' so that answers to problems can be 'formulated locally and in response to the particularities of local circumstance' (Letwin, 2005: 41-42). This would also have the effect of strengthening local institutions and networks, thereby conserving them in accordance with the conservative impulse. Letwin called this vision 'the Neighbourly Society'.

However, in the Neighbourly Society the concept of the state has receded as there is not the emphasis on state-redistributive oversight in the interest of positive liberty as under 
New Labour. The role of the state is limited to sustaining 'the balanced constitutional arrangements that frame the orderly community' (Buckler, 2007: 42). This paved the way for cuts to (rather than increase in) public spending and thus provided an ideological justification for the austerity programme which would characterise the Cameron government. These adjustments in the meanings of and relations between the concepts of liberty, state, society and community in Parliamentary Conservative Party ideology had significant implications for the ideology of the institution of English planning which has these concepts at its core.

This is most clearly seen in the transformation of the adjacent concept of the region, which became decoupled from the concepts of the state, community and liberty. Whereas the concept of the region was used by New Labour to think about the means by which greater equality of opportunity could be delivered through greater strategic state oversight and was presented as a means by which communities could influence their development plans, this was antithetical to the new Conservative ideology. Statutory regional planning was seen as overtly interventionist and redistributive and this triggered the conservative suspicion of the innate rationality of New Labour's statism, and the very idea that such imposed rationalities should override the free and 'organic' development of a functional economic area. Under this conception, regional development agencies were criticised by the then Minister for Planning as being 'a required creature of central government' without a sufficient degree of local accountability (House of Commons, 2011: Ev 65). 
The risk of unequal distribution of development opportunity and growth which so concerned New Labour and which may arise without strategic state oversight was entirely outweighed by the supposed benefits of the abolition of 'one-size-fits-all policies...imposed by the centre whether or not they work locally' (HM Government 2010: 5). Therefore, the ideological arrangement of concepts in the Parliamentary Conservative Party ideology had little acknowledgement of statutory strategic planning, preferring instead an institutional arrangement which gives greater plan-making powers to local areas. The conservative concept of 'community' as it relates to planning was therefore much more 'local' than under New Labour as it was less closely associated with the concepts of the state and a 'positive' form of liberty. This can be seen in the employment of the term 'neighbourhood' rather than 'community' in Conservative planning discourse. The swift dismantling of regional planning and the introduction of non-compulsory Neighbourhood Development Plans following the formation of the Conservative-led coalition government in 2010 was clearly influenced by this ideological morphology.

The transformed ideology of the institution of planning at the centre retains an emphasis on liberty - it is contained and controlled by the conservative conception of community, it is by no means rejected. However, it is a transformed conception of liberty in comparison with the more positive form under New Labour due to its decoupling from the concept of the state. There still remains the ideological imperative for deregulation, development, economic growth, choice, innovation, entrepreneurship and the creation of wealth. Indeed, it is these dimensions of liberty which the conservative ideology seeks to 
encourage in neighbourhoods through removing the 'artificial limits' imposed by the state and by empowering them to create neighbourhood plans. Theoretically, these qualities now work within the organic limits imposed, and given meaning, by local traditions and institutions. However, this brings with it the potential for tension under practical circumstances where the wishes of local communities are in conflict with the neoliberal emphasis on development and national development priorities. In the early stages, this tended to be glossed over: 'we can be both prodevelopment and prolocalist...decentralisation and development...I believe that they can and should reinforce one another' (Clark, 2010). This is not overly problematic at the abstract level of ideology. However, when political ideology collides with real world planning problems and the institution which has developed over time to address them, its latent internal incoherence is made manifest and it is forced to rearticulate itself in sometimes contradictory ways in order to arrive at and legitimise practical solutions (Lees \& Shepherd, 2015).

This tension is most clearly expressed in the ongoing conflict arising from the coexistence of the Coalition's localism agenda and the centrally directed emphasis on the need for the planning system to promote housebuilding and economic growth as enshrined in the National Planning Policy Framework (2012). While the localist aspect of the ideology influenced the removal of regional planning and the associated imposition of housing targets on local authorities, this new freedom also came with the responsibility of local authorities to set their own housing targets which must meet identified housing need. Local authorities therefore still had to deliver significant numbers of homes to meet local 
need, but instead of this being coordinated and negotiated (or 'imposed') at the regional level, it was up to numerous separate local authorities to do this work themselves within the context of the centrally-imposed National Planning Policy Framework (2012) which included a new 'presumption in favour of sustainable development'.

Therefore, despite the ideologically-driven removal of regional planning and the introduction of neighbourhood planning, plan-making and development management decisions at local level still had to meet housing need and the development objectives set out in centrally-imposed planning policy. It seems that the Coalition government could not entirely trust local areas to use their new freedoms in accordance with the neoliberal growth ambitions of central government, and so extended central state power through the mechanism of national planning policy so as to discipline local authorities and their communities in to delivering development, even against their wishes. In this way, we can see how the latent incoherence in the ideological amalgam of Cameronite Conservatism is institutionalised and made manifest through the practice of town and country planning.

\section{Conclusion}

The preceding brief analysis of the ideological influences on the institution of English planning under New Labour and the Conservative-led Coalition government has illustrated how the concepts of liberty, the state, community and society are of core importance to English planning. The analysis has shown that institutional adjustments in planning at the political centre can be related to how the competing political ideologies of 
New Labour and the Parliamentary Conservative Party sought to decontest these concepts. Both ideologies sought to use the concept of the community in similar ways to legitimise their ideological project, but with different institutional effects due to the different decontestations of the meanings of and relations between the concepts of liberty, society and the state. These differences influenced different decontestations of the adjacent concept of the region, and therefore influenced the institutional structure of national English planning surrounding regions.

However, it should be emphasised that this paper is not arguing that this is where the explanation for institutional change must end. It is clear that there are other factors, not least pragmatism, political convenience and error rather than conspiracy. A full analysis of institutional change in national planning requires a theory which can also handle the agency side of the social scientific equation, and how different factions and interest groups both within the policymaking sphere and outside of it seek to shape the process through exerting power to create desired effects (which may be more or less successful). Nevertheless, the theory outlined here can help us think about the way in which ideology can shape the terms by which a policy problem is understood and communicated, and the way in which it is used to construct, legitimise and deliver institutional change. It also illustrates that any political ideology seeking to influence planning must do so on planning's terms - when seeking to impose its meanings on planning an ideology must navigate planning's own ideological legacies. 
By conceptualising the institution of planning in the way outlined in this paper, the language of analysis which becomes available is one that has been developed by political theorists specifically to help us think about how political ideologies seek to adjust the terms by which political reality is understood, and therefore seek to lay out a programme for public political institutions. It thus turns our attention to the conceptual ideological structure of the institution of planning, and prompts an analysis of those deeply political concepts which give planning its form and which are also of concern to national political ideologies. By understanding how competing political ideologies seek to adjust the meanings of and relations between such concepts in planning, we can understand the rationale for some of the institutional adjustments at the political centre. This is important, as it is the institutional framework for planning set by the political centre which sets the terms of what is thinkable and therefore deliverable at the lower tiers of planning practice.

The theory therefore provides a partial explanation for the stability and dynamism of the institution of English planning. In this sense, the institution of planning mirrors this quality of ideologies. It retains a degree of conceptual and structural coherence due to the ongoing presence and influence of fundamental concepts such as liberty, society, community and the state without which it would arguably cease to exist as an institution. Yet these concepts are prone to ongoing contestation and, therefore, change. It is not the case that these concepts can be made to mean anything - it is a function of ideologies to limit the range of their contestation. Thus some degree of institutional and ideological coherence endures, despite changes in meaning. This opens out the theorising of planning 
as comprising competing and distinct ideologies. Planning is not 'one ideology or three' (Foley, 1960) - it is a complex and dynamic relational structure of ideologically contested concepts whose shifts can have significant implications for the policy programmes for planning set by the political centre and can create logical incoherence which finds expression in a fragmented policy framework. Crucially, using the theory set out here, this structure can be analysed, the particularities of shifts in meaning and the resultant shifts in policy programme understood.

The context selected to illustrate the theory in this paper has been the English planning system and debates surrounding the transition from New Labour to Conservative dominance. The concepts identified as being of core structural importance to planning are therefore a function of the social and political history of planning in England. These concepts may not therefore be of core importance for planning in other contexts. However, the theory outlined here can be applied to different national contexts through an analysis of the characteristics of the main national political ideologies and the institutional histories of planning in those countries. In this way, concepts core to planning in other contexts can be identified and their structural shifts understood.

\section{References}

- Allmendinger P and Haughton G (2015) Post-political regimes in English planning: from Third Way to Big Society. In: Metzger J, Allmendinger P and Osterlynck S (eds) Planning Against the Political: Democratic Deficits in European Territorial Governance. London: Routledge, pp.29-54. 
- Allmendinger P \& Thomas H (1998) Urban planning and the British new right. London: Routledge.

- Barker R (1997) Political ideas in modern Britain $2^{\text {nd }}$ edition. London \& New York: Routledge.

- Beech M (2004) New Labour. In: R. Plant, M. Beech \& K. Hickson (eds). The struggle for Labour's soul: Understanding Labour's political thought since 1945. London \& New York: Routledge. pp. 86-102.

- Béland D and Cox RH (eds) (2011) Ideas and Politics in Social Science. Oxford: Oxford University Press.

- Berlin I ([1958] 2001) Two concepts of liberty. In: Warburton N Freedom: An Introduction with Readings. London and New York: Routledge, pp.127-136.

- Bevir M (2005) New Labour: a critique. London \& New York: Routledge.

- Blair T (1998) The third way: a new politics for a new century. London: The Fabian Society.

- Blond P (2009) Rise of the red Tories. Prospect. 28 February 2009. Available at: http://www.prospectmagazine.co.uk/features/riseoftheredtories (accessed 6 January 2016).

- Blyth M (2002) Institutions and ideas. In: Marsh D and Stoker G (eds) Theory and Methods in Political Science. Houndmills and New York: Palgrave McMillan, pp.292-310.

- Buckler S (2007) Theory, ideology, rhetoric: Ideas in politics and the case of 'community' in recent political discourse. The British Journal of Politics and International Relations 9(1): 36-54. 
- Clark G (2010) Community-led development, speech given to the Royal Town Planning Institute Annual Planning Convention, 29 June 2010. Available at: http://www.gregclark.org/articles speeches/communityleddevelopmentaspeechtot heroyal/10 (accessed 4 April 2016).

- Conservative Party (2006) Built to Last: The Aims and Values of the Conservative Party. London: The Conservative Party.

- Conservative Party (2009a) Control shift - returning power to local communities. Policy Green Paper Number 9. Brentford: TPF Group.

- Conservative Party (2009b) Strong foundations - building homes and communities. Policy Green Paper Number 10. Brentford: TPF Group.

- Conservative Party (2010) Open source planning. Policy Green Paper Number 14. Brentford: TPF Group.

- Cullingworth B \& Nadin V (2006) Town and country planning in the UK. 14th edition. Abingdon: Routledge.

- Dommett K (2012) Conceptualising party political ideology: an exploration of party modernisation in Britain. PhD Thesis, University of Sheffield, UK.

- Dorey P (2007) A new direction or another false dawn? David Cameron and the crisis of British Conservatism. British Politics 2(2): 137-166.

- Driver S \& Martell L (1997) New Labour's communitarianisms. Critical Social Policy, 17(52): 27-46. Available at: doi: 10.1177/026101839701705202 (accessed 14 April 2016).

- DTLR (Department of Transport, Local Government and the Regions) (2001) Planning: delivering a fundamental change. London: HMSO. 
- DTLR (Department of Transport, Local Government and the Regions) (2002) Sustainable communities: delivering through planning. London: HMSO.

- Eagleton T (2007) Ideology: An Introduction, new and updated edition. London: Verso.

- Eccleshall R (1986) British liberalism: liberal thought from 1640s to 1980s. London \& New York: Longman.

- Evans S (2010) 'Mother's boy': David Cameron and Margaret Thatcher. The British Journal of Politics and International Relations 12 (3): 325-343.

- Foley DL (1960) British town planning: one ideology or three? The British Journal of Sociology 11(3): 211-231.

- Freeden M (2003) Ideology: A Very Short Introduction. Oxford: Oxford University Press.

- Freeden M (1996) Ideologies and Political Theory: A Conceptual Approach. Oxford: Oxford University Press.

- Freeden M (1998) Ideologies and Political Theory: A Conceptual Approach. [ebook] Oxford: Oxford University Press. Available at Oxford Scholarship Online: http://www.oxfordscholarship.com/view/10.1093/019829414X.001.0001/acprof9780198294146 (accessed 18 July 2013).

- Freeden M (2013) The morphological analysis of ideology. In: Freeden M, Sargeant LT and Stears MS (eds) The Oxford Handbook of Political Ideologies. Oxford: Oxford University Press, pp.115-134. 
- Gallie WB (1956) Essentially contested concepts. Proceedings of the Aristotelian Society, New Series 56(1955-56): 167-198.

- Gray J (1997) The undoing of Conservatism. In: Gray J and Willetts D Is Conservatism Dead? London: The Social Market Foundation and Profile Books Ltd, pp.1-65.

- Green TH [1888] (2011) Lecture on liberal legislation and freedom of contract. In: R.L. Nettleship (ed), Works of Thomas Hill Green Volume 3. Cambridge: Cambridge University Press. pp. 365-386.

- Haar, CM (1951) Land planning law in a free society. Harvard: Harvard University Press.

- Hay C (2002) Political Analysis: A Critical Introduction. Houndmills and New York: Palgrave.

- Hay C (2009) Constructivist institutionalism. In: Binder SA, Rhodes RAW and Rockman BA (eds) The Oxford Handbook of Political Institutions. [ebook] Oxford Handbooks Online. Available at: DOI:

10.1093/oxfordhb/9780199548460.003.0004 (accessed 8 April 2016), pp.56-74.

- Haughton G and Allmendinger P (2016) Think tanks and the pressures for planning reform in England. Environment and Planning C: Government and Policy 34(8): 1676-1692.

- HC Deb 17 December 2002 vol 396 cc 729-816 Available at: http://www.publications.parliament.uk/pa/cm200203/cmhansrd/vo021217/debtext /21217-15.htm\#21217-15_head2 (accessed 10 April 2016). 
- Heywood A (2012) Political Ideologies: An Introduction. 5th edition.

Houndmills, Basingstoke: Palgrave Macmillan.

- HM Government (2010) Decentralisation and Localism Bill: an essential guide. London: DCLG.

- House of Commons, Communities and Local Government Committee (2011) Abolition of regional spatial strategies: a planning vacuum (HC 517, Second report of session 2010-11) - Volume I: Report, together with formal minutes, oral and written evidence. London: TSO (The Stationary Office Limited).

- Jessop RD (2003) From Thatcherism to New Labour: neo-Liberalism, workfarism, and labour market regulation. In: Overbeek H (ed) The Political Economy of European Employment: European Integration and the Transnationalization of the (Un)employment Question. London: Routledge, pp. 137-153.

- Labour Party (2001) Ambitions for Britain: Labour's Manifesto 2001. Available at: http://www.politicsresources.net/area/uk/e01/man/lab/lab01.htm (accessed 10 April 2016).

- Labour Party (2005) The Labour Party Manifesto 2005 Available at: http://www.politicsresources.net/area/uk/ge05/man/lab/manifesto.pdf (accessed 10 April 2016).

- Labour Party (2014) Labour Party rule book 2014 Available at: https://rotherhampolitics.files.wordpress.com/2014/08/rule-book-2014-collinsreview.pdf (accessed 31 March 2016). 
- Lees E and Shepherd E (2015) Incoherence and incompatibility in planning law. International Journal of Law in the Built Environment 7(2): 111-126.

- Letwin O (2002) Sustainability and society, speech given to the Adam Smith Intitute, 3 July, 02. Available at: http://www.webarchive.org.uk/wayback/archive/20080908030046/http://www.co nservatives.com/tile.do?def=news.story.page\&obj_id=33854\&speeches $=1$ (accessed 11 April 2016).

- Letwin O (2003) The Neighbourly Society: Collected Speeches 2001 - 2003. London: Centre for Policy Studies.

- Letwin O (2005) Healthy cities, healthy countryside. In: Tate J (ed) What's Right Now: Conservative Essays on the Role of Civil Society, Markets and the State. London: The Social Market Foundation.

- Nadin V \& Stead D (2008) European spatial planning systems, social models and learning, The Planning Review 44(172): 35-47.

- Parker G \& Doak J (2012) Key Concepts in Planning. Los Angeles: Sage.

- Reade E (1987) British Town and Country Planning. Milton Keynes: Open University Press.

- Schmidt VA (2008) Discursive institutionalism: The explanatory power of ideas and discourse. Annual Review of Political Science 11(1): 303-326.

- Schmidt VA (2010) Taking ideas and discourse seriously: explaining change through discursive institutionalism as the fourth 'new institutionalism'. European Political Science Review 2(1): 1-25. 
- Schmidt VA (2011) Reconciling ideas and institutions through discursive institutionalism. In: Béland D \& Cox RH (eds) Ideas and Politics in Social Science Research. Oxford: Oxford University Press, pp.47-64.

- Shepherd E (2016) Liberty, property and the state: the ideology of the institution of national English town and country planning. PhD Thesis, University of Cambridge, UK.

- Tewdwr-Jones M (2002) The planning polity: planning, government and the policy process. London and New York: Routledge.

- Tewdwr-Jones M (2012) Spatial Planning and Governance. Basingstoke: Macmillan.

- Waterhout B Othengrafen F \& Sykes O (2013) Neo-liberalization processes and spatial planning in France, Germany, and the Netherlands: An exploration, Planning Practice \& Research, 28(1): 141-159.

- Willetts D (1992) Modern conservatism. London: Penguin Books.

- Willetts D (1997) Conclusion. In: Gray J and Willetts D Is Conservatism Dead? London: The Social Market Foundation and Profile Books Ltd, pp. 142-180.

- Willetts D (2005) Compassionate Conservatism and the war on poverty, speech given to Centre for Social Justice at the Harrow Club, London 6 January, 05. Available at: http://www.webarchive.org.uk/wayback/archive/20080908025202/https://www.co nservatives.com/tile.do?def=news.story.page\&obj_id=118477\&speeches $=1$ (accessed 11 April 2016). 
- Zonneveld W (2005) In search of conceptual modernization: The new Dutch 'national spatial strategy', Journal of Housing and the Built Environment 20(4): 425-443. 